\title{
Miningo
}

\section{Development of a Method to Measure Charges in Tumbling Mills}

\section{Desenvolvimneto de método para medição de cargas em moinhos tubulares}

Eduardo Nozawa Caetano de Araujo

Mining and Mineral Processing Engineer

Metso Brazil

Iporanga - Sorocaba - SP

eduardo.nozawa@metso.com

\section{Prof. PhD. Homero Delboni Jr.}

Mining and Petroleum Engineering Department University of Sao Paulo Brazil

Butantã - Cidade Universitária - São Paulo hdelboni@usp.br

\section{Abstract}

Tumbling mills are often taken as the object of optimization studies because they are a type of equipment that consume large amounts of energy. Among the current available resources to conduct such studies, mathematic modelling presents great efficiency due to its low cost, speed and reliability.

The total charge and grinding media charge are very important variables to conduct modelling exercises that aim at power draw and product size distribution forecasting. However, the common measurement methods require people entering the equipment, which carries a number of adversities related to confined spaces.

In this regard, this paper presents the development of a method and the prototype of a device able to measure tumbling mill charges, quickly, precisely, with low cost and, above all, ensuring safety.

The result of this work is a method that allows equivalent or superior precision in comparison to the existing methods, whose main aspect is to eliminate the requirement of people entering dangerous environments, such as tumbling mills.

Keywords: mills, safety, grinding, charge.

\section{Resumo}

Moinhos de bolas são, frequentemente, objeto de estudos de otimização, pois são equipamentos que consomem muita energia. Tais estudos são conduzidos sistematicamente sob enfoque de modelagem matemática, pois tal recurso é rápido, eficiente, de alta confiabilidade e de baixo custo.

A carga total e carga de corpos moedores são variáveis muito importantes para exercícios de simulação, que visam a estabelecer previsões de potência de operação $e$ distribuições granulométricas. Entretanto medições de graus de enchimeto requerem medições por pessoas na câmara de moagem, sob condições de risco elevado associados a espaços combinados.

Nesse aspecto, o presente trabalho mostra o desenvolvimento de um método $e$ um protótipo de um dispositivo para medição de cargas em moinhos tubulares, de forma precisa, rápida e com baixo custo e, acima de tudo, que minimiza riscos. $O$ resultado é um método com precisão igual ou maior do que dispositivos semelhantes, cujo principal aspecto é apenas o de eliminar o risco associado a pessoasl entrarem em câmaras internas de moinhos tubulraes.

Palavras-chave: moinhos, moagem, carga.

\section{Introduction}

The motivation to develop a device able to measure charge levels in tumbling mills arose from the experience in sam- 
pling campaigns, which is an essential step in milling circuit optimization studies.

Entering a mill requires the accomplishment of a number of requirements that several times consumes costly time for the mining companies due to plant interruptions. These requirements cannot be dismissed as they are closely associated to safety and health, themes that must be taken as priority in an industry historically known for its hazard environment. Thus, a form of eliminating, or at least reducing some risks, would be for the people to avoid entering the equipment by using a device placed outside the confined space.

\section{Common Methods to Measure Tumbling Mills Charges}

The charge level of a mill can be described as the volume occupied by the grinding media (including empty spaces) as a fraction of the total volume available inside the equipment. Assuming this definition, other measurements may be taken considering the total charge

Under a practical point of view, usually three or four measurements of $S$ are taken. On the other hand, there is an

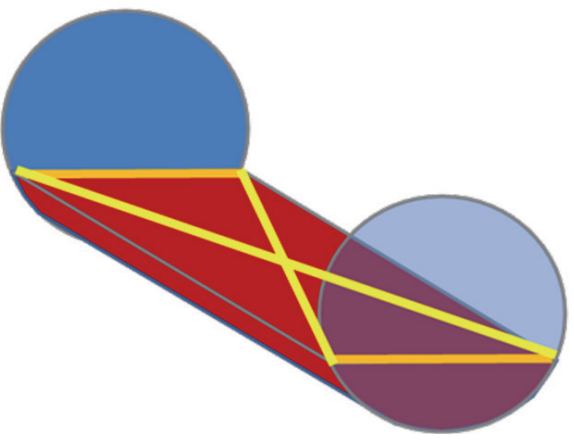

Allis Chalmers (apud Napier Munn et al., 1996) proposed the fol-

Where:

$H=$ height from top liners and the

Morrell (1994) demonstrated that Equation 1 presents errors when measuring charge levels below 20\%, a common situation in SAG mills. In addiction to that, many times there are

\section{MCP Method}

Some premises were considered for alternatives to the common methods. However the mathematical treatment of a cloud of points describing the mill's internal surface presented the most suit- that includes the rock charge; in this case, applicable to SAG and AG mills.

The charge level is the variable that most contributes to the power draw. It is completely relevant to know the charge level in sampling campaigns, and during operation, in order to succesfuly

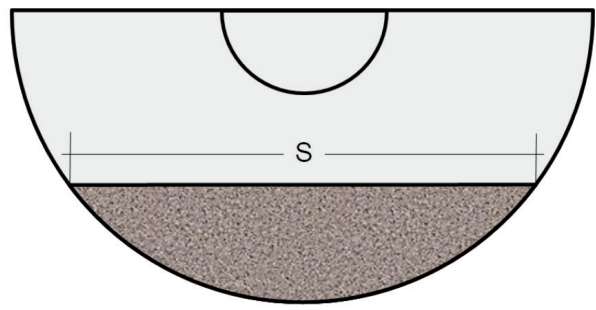

indirect procedure to obtain other two measurements considering the diagonal of the rectangular surface that describes the

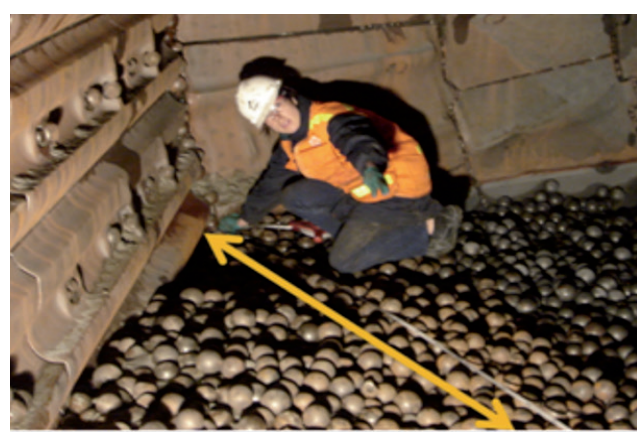

lowing formula that considers the height between liners on the top position and

$$
V=113-\left(\frac{H}{D} \times 126\right)
$$

charge surface level (m)

$$
D=\text { mill diameter }(\mathrm{m}) \text {, inside liners }
$$

practical limitations for measuring the heights of large diameter mills.

Another way, almost not documented, but very oftern praticed, is the counting of exposed liners in order to

able solution for the pre-established requirements. The main aspects considered were: to avoid people entering the mills and costs.

A prototype was built and named conduct mathematical modelling and simulations.

The common technique to measure the charge level of tumbling mills requires at least two people measuring the charge width (S), as exemplified on the Figure 1.

Figure 1

Charge Geometry description

charge level. In this case, $\mathrm{S}$ is calculated considering the belly length. Figure 2 ilustrates these diagonals.

Figure 2

Diagonals of the charge surface

the charge surface.

find the equivalent $\alpha$ angle, also ilustrated in Figure 1. The error, in this case, depends on the interpretation of the fraction of exposed liners that are in contact with the charge.

MCP or Mill Charge Profiler. The instrument was designed to measure the position of a number of points within the limits of a confined space, describing these points by spherical coordinates and a laser distance 
meter. The base of the device was inspired from an Alt-Azimutal mechanism. Some modifications were adapted in order to allow a wider angular range, suitable

Figure 3 Mill Charge Profiler

After preliminary tests, the device demonstrated successfully that it was able to generate the desired cloud of points. In order to interpret the cloud data, a mathematical treatment that followed through a number of steps considering vectorial corrections, orthogonal projections, curve

Figure 4

Projection of the cloud onto the plane $X Y$

Time could be saved during the placement of the device because it was not necessary to apply any bubble leveling procedure. The mathematical data treatment was able to determine the position of the plane, the coordinates of the circumference center and its radius and finally the coefficients that describes the

\section{Results}

Three equipment surfaces were measured. The first equipment was a flotation column not yet installed and stored on the horizontal position. Regardless of not being a mill itself, the internal surface was very similar to the proposed problem and the cell to measure mill's internal from its feed trunion. The laser distance meter chosen was a Bosch DLE 50, able the measure up to $50 \mathrm{~m}$ with precision of $1.5 \mathrm{~mm}$.
The measurements of angles were made through protractors with precision of 0.5 degree. Figure 3 illustrates photographs of the MCP

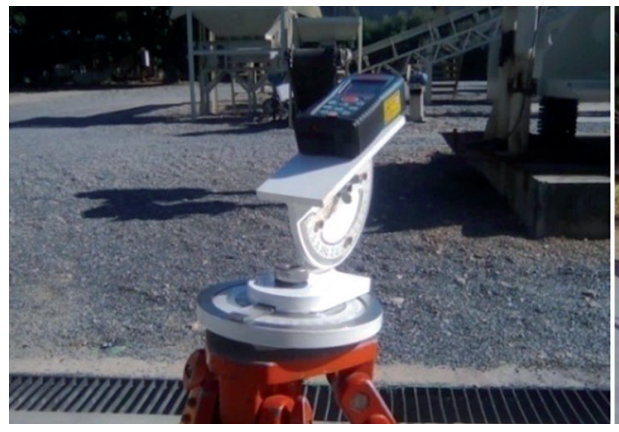

fitting and error estimates was developed.

In spite of being a 3D problem, the interpretation was built in 2D through the projection of all captured data points onto a plane perpendicular to the mill center line. Figure 4 illustrates the projection of the cloud on the mentioned plane. The

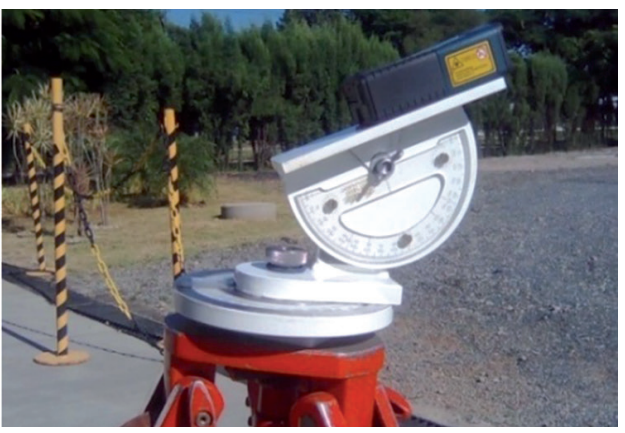

points corresponding to the liners (blue crosses) were projected (orange arrows) to fit a circumference (orange dashed circunference) and the points corresponding the charge (red crosses) were projected (green arrows) to fit by a polynomial (green dashed line).

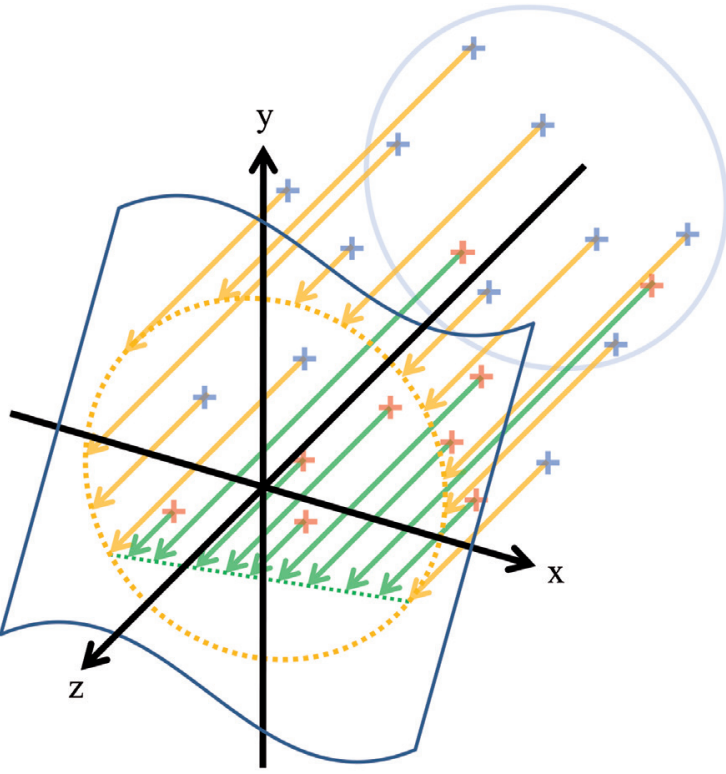

polynomial that fits to the points associates to the charge.

Once found the mathematical descriptions of the circumference and the polynomial, the area ocupied by the charge is then calculated.

Later, the fit error is estimated through the deviation of the circumfer- ence radius with estatistical distribution and confidence interval. Invariably, the average distance among the projected points and the circumference is zero, but the individual distances deviation can be estimated through $\mathrm{t}$-student distribuition due to the limited amount of points, usually fewer than 30 was considered the base case of the test campaign due to its dimensional confidence. The second equipment was measured during a maintenance stop. It was a ball mill installed in a bauxite processing plant. The third equipment was a SAG mill with $32^{\prime}(9.75 \mathrm{~m}) \mathrm{di}$ - ameter, installed in a gold and copper plant. The measurements in the SAG mill were conducted after a grind out. Figure 5 illustrates photographs of the equipment and the Figure 6 demonstrates an example of projected points, fitted circumference and polynomial. 

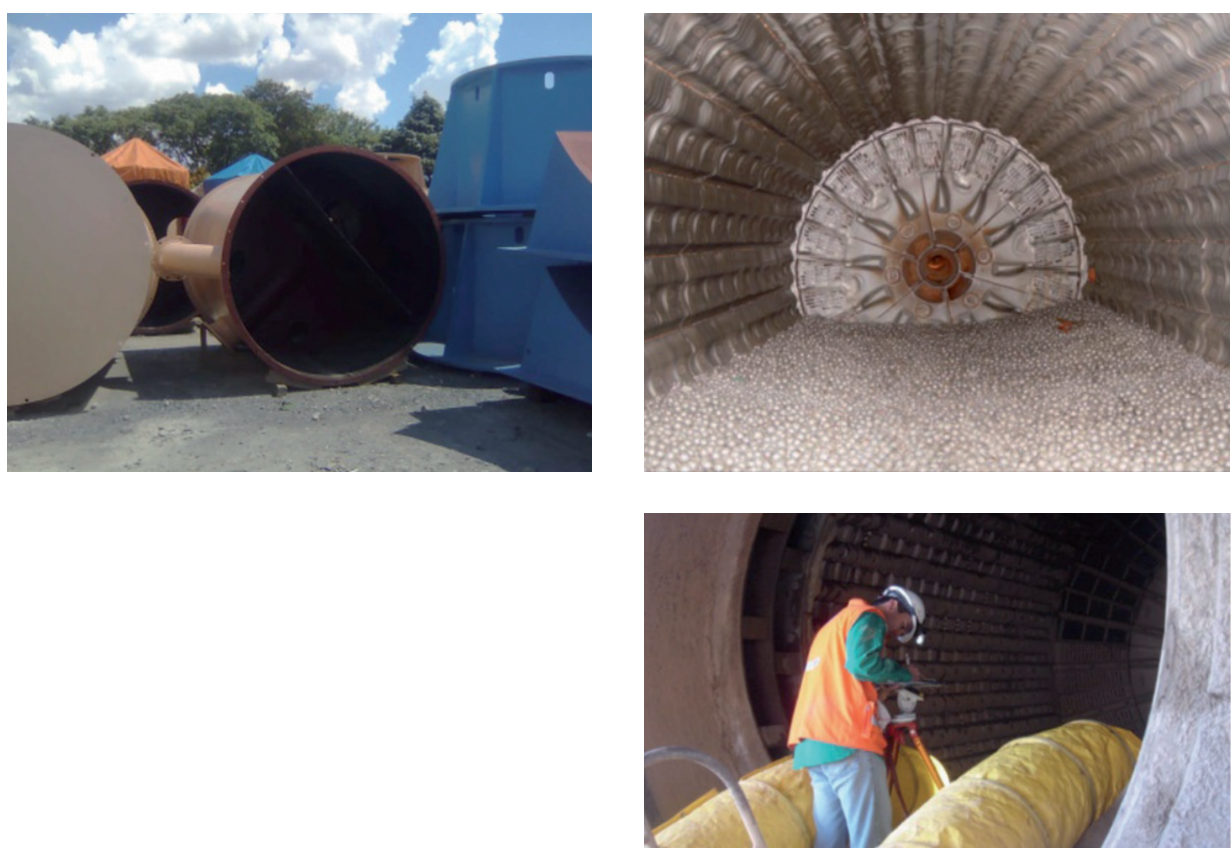

Figure 5

Measured equipment
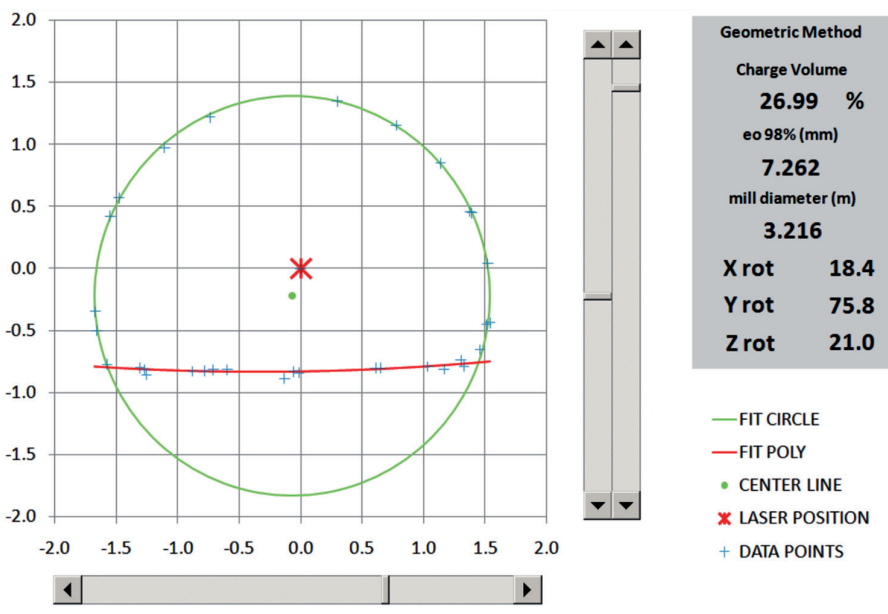

For each type of equipment, the other possible common methods. Table 1 summarizes the results. charge level was also calculated through

\begin{tabular}{r|c|c|c|c|c}
\hline Measurement Method & Diameter (m) & $\begin{array}{c}\text { Charge Level } \\
(\%)\end{array}$ & $\begin{array}{c}\text { Minimum } \\
\text { charge level } \\
(\%)\end{array}$ & $\begin{array}{c}\text { Maximum charge } \\
\text { level }(\%)\end{array}$ & $\begin{array}{c}\text { Radius } \\
\text { error, } \\
\text { Cl 98\% }\end{array}$ \\
\hline Flotation Cell Height & 2.418 & 38.5 & - & - & - \\
\hline Allis Chalmers & $2.418^{*}$ & 38.4 & - & - & - \\
\hline MCP & 2.418 & 38.5 & - & - & 0.25 \\
\hline Ball Mill Swidth & $3.22^{*}$ & 30.7 & 27.9 & 34.2 & - \\
\hline Height & $3.22^{*}$ & 26.0 & 25.6 & 26.4 & - \\
\hline Allis Chalmers & $3.22^{*}$ & 25.6 & 25.2 & 26.0 & - \\
\hline Exposed liners counting & $3.22^{*}$ & 28.2 & 24.3 & 32.3 & - \\
\hline MCP & 3.216 & 27.0 & - & - & 0.43 \\
\hline SAG Mill Mill design & 9.52 & - & - & - & - \\
\hline S width & $9.54^{*}$ & 17.9 & 17.6 & 18.2 & - \\
\hline Height & $9.54^{*}$ & 18.5 & 18.4 & 18.6 & - \\
\hline Allis Chalmers & $9.54^{*}$ & 17.3 & 17.2 & 17.3 & - \\
\hline Exposed liners counting & $9.54^{*}$ & 17.5 & 16.2 & 18.8 & - \\
\hline MCP & 9.535 & 18.6 & - & - & 0.37 \\
\hline
\end{tabular}

Table 1

Results Summary *assumed values 


\section{Discussions}

The accuracy estimated for the flotation column diameter was considered to be excellent, taking into account that the MCP was designed with an angular precision of 0.5 degrees and distance precision of $1.5 \mathrm{~mm}$. An error of $3.0 \mathrm{~mm}$ on the radius within the confidence interval of $98 \%$ achieved the expectations for this case, and was considered ideal. The calculated relative error was $0.25 \%$. In the ball mill, the estimated error for the radius was calculated as $7.3 \mathrm{~mm}$. Considering that the liners were worn and that it was not possible to ensure that the laser was pointed precisely at the bottom region of the liner waves, this error can be considered very acceptable and consistent with the base case. In this equipment, the relative error was $0.43 \%$. In the SAG mill, the estimated error was $18 \mathrm{~mm}$ and the calculated diameter was $9.535 \mathrm{~m}$. Consulting design drawings, the diameter inside liners would be 9.52 $\mathrm{m}$, thus the value calculated with the MCP was very consistent, even considering the liners wear. The relative error for the SAG mill was $0.37 \%$. Among all the studied cases, all the errors presented consistent values, with the same magnitude.

In the flotation column, four direct measurements were taken of its diameter, resulting in a very accurate average of $2.418 \mathrm{~m}$. The diameter calculated through the MCP was identical. The "charge" was calculated to be $38.5 \%$ with the MCP and through the direct measurement of the "charge" height (true value). Applying the diameter and the height to the Allis Chalmers formula, the result obtained was $38.4 \%$, indicating that the formula was valid for this test that presented a high "charge" level.

In the ball mill, measurement by MCP resulted in a charge level of $27.0 \%$.

\section{Conclusions}

The MCP demonstrated to be a feasible, precise and safe alternative to measure the charge of tumbling mills. The MCP avoids the entrance of people into the mills which are confined spaces, frequently characterized by inhospitable conditions such as high temperatures and humidity, risks of falling, slipping, explosion and falling balls, presence of toxic gases, among others.

The mathematical treatment demonstrated to be efficient, fast and did not de-
The measurements conducted with $\mathrm{S}$ width presented a wide variability, with an average of $30.7 \%$ that could be between 27.9 and 34.2 with $90 \%$ confidence. Considering the heights, the obtained results were 25.6 and $26.4 \%$, and applying the Allis Chalmers formula, the results were 25.2 and $26.0 \%$. Counting the exposed liners, the charge value was estimated to be $28.2 \%$

The value of $30.7 \%$ obtained through the $S$ width method was superestimated in comparison to the other methods. The methods that take the height as the main input presented results below $26.5 \%$, but it should be taken into account that the central portion of the charge had a lower level in comparison to the edges in contact with cilinder liners. This observation also explains the higher charge $(28.2 \%)$ estimated using the method of counting the exposed liners.

The measurement through the $S$ width method presented differences of up to $5 \mathrm{~cm}$, which is very acceptable, considering the charge shape irregularity, the difficulty in establishing a criterion defining the beginning and the end of the measurement, and also the difficulty in keeping a regular stretching on the measurement tape.

When converting the diagonal measurements into the equivalent $S$ width, increased differences between the equivalent $S$ width were observed. The original measurements of the diagonal were 7.10 and $7.14 \mathrm{~m}$ and the equivalent $S$ width for these diagonals were 3.03 and $3.12 \mathrm{~m}$. Thus, the difference increased from 4 to $9 \mathrm{~cm}$. The equivalent $S$ width of diagonal resulted in completely distinct charge levels of 29.2 and $35.1 \%$.

In the SAG mill, in addition to the difficulties previously mentioned, the typical pushing environment of the

mand the application of any CAD software for the interpretation of results. It did not require the use of equipment bubble leveling or the taking of an origin point. With this concept, about 10 minutes could be saved during the measurements.

A device with a more precise angular resolution could contribute to a more accurate result. In addition, the way of interpreting the calculated errors, it should be taken into account that the liner surfaces industrial plants was experienced, due to production demands. Before the application of the MCP, a survey campaign involving the collection of a number of samples in several points of the plant was conducted with PI data instruments and at the end a crash-stop was followed by a grind out of the SAG mill.

The measurements with the MCP resulted in a charge level of $18.6 \%$. The measurements taken through the $S$ width presented low variability. On the other hand these values were sistematically lower. The average charge level calculated through the $S$ width method was $17.9 \%$ that could be between 17.6 and $18.2 \%$ within a confidence interval of $90 \%$.

For the calculations solely considering the heights, the obtained results were 18.4 and $18.6 \%$, which were very close to the MCP results and also took into account that the charge presented a flat shape. Applying the Allis Chalmers formula, the obtained value was $17.3 \%$, which is out of the valid range (the formula is valid for charge levels above $20 \%)$. Through the counting of exposed liners, the charge level was estimated to be between 16.2 and $18.8 \%$

The $S$ widths presented differences of up to $3 \mathrm{~cm}$ on the direct measurements and also on the diagonals, which is very acceptable considering all the irregularities and the internal size of the SAG.

A small increased difference between the equivalent $S$ width calculated from the diagonals measurements was noted. The original measurements were $12.44 \mathrm{~m}$ and $12.46 \mathrm{~m}$ and the equivalent $\mathrm{S}$ width for these diagonals were 8.03 and $8.06 \mathrm{~m}$. These differences did not result in contradictory charge level such as observed in the ball mills. The obtained values were 17.4 and $17.6 \%$.

have irregularities that cannot be precisely evaluated while pointing the laser. Moreover, there are variations due to liner wear.

Thus, the measurement errors should predictably achieve the magnitude of a few milimeters.

Regarding the errors of the charge measurement points, a plausible interpretation is that the empty spaces among balls do not define a completely flat surface, so the variation of these measurements are ex- 
pected to be on the scale of centimeters. The precision of the laser is on the milimeters scale, so it does not make sense to estimate an error for the charge surface.

On the $S$ width method, small direct measurement differences cause big variations on the charge level estimatives and the trend of such errors is to increase in smaller diameter mills, which is the case of the measured ball mill.
The MCP eliminates vague criterias adopted by people while measuring mill internally by common methods. Among these criteria, the physical limits of the charge and the measuring tape stretch.

\section{References}

AL-SHARADQAH, A. CHERNOV, N. Error analysis for circle fitting algorithms, Electronic Journal of Statistics, 886-911, 2009.

BERALDO, J.L. Moagem de minérios em moinhos tubulares. São Paulo: Editora Edgard Blücher, 1987.

BOND, F.C. Crushing and grinding calculations. Allis Chalmers Publication, n. 07R9235B, 1961

CHAVES, A.P. Teoria e prática de tratamento de minérios, britagem, peneiramento e moagem. São Paulo: Signus Editora, 1999. v. III.

CHERNOV, N. LESORT, C., Least squares fitting of circles. Journal of Mathematical Imaging and Vision, 239-251, 2005.

HUMES, A.F.P. de C. et al. Noções de Cálculo Numérico. São Paulo: McGraw-Hill do Brasil, 1984, p.93-109, 158-174.

LASDON, L.S., WAREN, A.D., Generalized reduced gradient software for linearly and nonlinearly constrained problems. in: Greenberg, H.J., (Ed.) Design and implementation of optimization software. Sijthoff and Noordhoff, Holanda, 1978, p.335-362.

MOON P, SPENCER DE. Spherical coordinates $(r, \theta, \psi)$. Field theory handbook, including coordinate systems, differential equations, and their solutions. New York: Springer-Verlag. pp. 24-27, 1988. p. 24-27. (2nd and 3rd print corrected)

MORRELL S. Power draw of grinding mills - Its measurement and prediction. $5^{\text {th }}$ Mill Ops Conf, Roxby Downs, Oct, 109-114 (AusIMM), 1994.

MORRELL S. Power draw of wet tumbling mills and its relationship to charge dynamics. Trans Inst Min Metall, 105, Jan-Apr, 1996.

NAPIER MUNN, T.J., MORRELL, S., MORRISON, R.D., KOJOVIC, T. Mineral comminution circuits - their operation and optimisation. Brisbane - AU:Napier Munn, T.J. Ed., JKMRC, 1996.

NR-33 Segurança e Saúde nos Trabalhos em Espaços Confinados, Publicação D.O.U, Portaria SIT n.o 202 22/DEZ/2006.

ROWLAND Jr, C.A. Selection of rod mills, ball mills, pebble mills and regrind mills. Design and installation of comminution circuits (Eds: Mular and Jergernsen), SNE/AIME, New tork, p.393-438, 1982.( Eds.: MULAR and JERGERNSEN)

ROWLAND Jr, C.A., KJOS, D.M. Rod and ball mills. Ch12 in Mineral Processing Plant, SME, 1978. 883p. (Eds.: MULAR and JERGERSEN).

ROBINSON S.M., Fitting spheres by the method of least squares Commun. Assoc. Comput. Mach. 4, 491, 1961.

TAGGART, A.F. Handbook of mineral dressing. New York: Wiley, , 1945.

TAUBIN, G. Estimation of planar curves, surfaces and nonplanarspace curves defined by implicit equations, with applications to edge and range image segmentation. IEEE Trans. Pattern Analysis Machine Intelligence 13 1115-1138, 1991.

Received: 11 January 2011 - Accepted: 18 August 2014. 